\title{
PENERAPAN METODE ANALYTICAL HIERARCHY PROCESS DAN TECHNIQUE FOR ORDER PREFERENCE BY SIMILARITY TO ORDER SOLUTION DALAM SELEKSI PENERIMAAN MAHASISWA BARU JALUR BIDIK MISI
}

\author{
Zen Munawar,ST,S.Kom., M.Kom \\ Dosen Prodi Manajemen Informatika \\ Politeknik LP3I Bandung \\ E-mail:munawarzen@gmail.com
}

\begin{abstract}
Abstrak : Metode Analytical Hierarchy Process (AHP) di gunakan untuk mengambil suatu keputusan dengan cara membandingkan secara berpasangan setiap kriteria yang di miliki oleh suatu permasalahan sehingga di dapat suatu bobot nilai dari kepentingan tiap kriteria - kriteria yang ada, dan Technique for Order Preference by Similarity to Order Solution (TOPSIS) di gunakan untuk mencari solusi yang paling ideal dan kebutuhan masalah yang ada, dalam hal ini dilakukan dalam menyeleksi penerimaan mahasiswa baru jalur bidik misi dengan cara di berikan bobot nilai sesuai dengan kebutuhan. Terdapat rumusan masalah yaitu bagaimana menentukan bobot nilai pada seleksi mahasiswa jalur bidik misi. Adapun Tujuannya mengembangkan sistem pendukung keputusan dalam seleksi mahasiswa jalur bidik misi. Sistem pendukung keputusan (SPK) dalam seleksi penerimaan mahasiswa ajalur bidikmisi dapat menyimpan data kriteria, data mahasiswa, data prioritas kriteria, dan menganalisis bobot nilai kriteria serta alternatif mahasiswa dengan menggunakan metode AHP dan TOPSIS, hasil dari analisis tersebut dapat digunakan untuk pelaporan penerimaan mahasiswa jalur bidikmisi. Metode AHP dan TOPSIS dapat menentukan alternatif mahasiswa terbaik hal ini terbukti dengan mahasiswa yang memiliki nilai tertinggi dari hasil perhitungan TOPSIS dan AHP yang di pilih. Sistem pendukung keputusan penerimaan calon mahasiswa bidikmisi menggunakan metode AHP dan TOPSIS dapat di kembangkan dengan membandingkan metode keduanya. Diharapkan ada yang melakuakan pengembangan lebih lanjut untuk masalah yang lain, bahkan yang lebih kompleks dengan jumlah kriteria dan alternatif yang lebih banyak
\end{abstract}

Kata Kunci : Analytical Hierarchy Process, Technique for Order Preference by Similarity to Order Solution, Sistem Pendukung Keputusan

\section{Pendahuluan}

Perguruan tinggi merupakan salah satu bentuk jenis pendidikan yang menyediakan beasiswa bidikmisi bagi calon mahasiswanya. Dengan banyaknya pencari beasiswa menyebabkan sulitnya universitas untuk menentukan calon mahasiswa mana yang akan diberikan beasiswa. Selain itu banyaknya kriteria yang berpengaruh pada proses penerimaan calon mahasiswa beasiswa membingungkan universitas untuk menentukan kriteria mana yang harus diutamakan. 
Metode AHP di gunakan untuk mengambil suatu keputusan dengan cara membandingkan secara berpasangan setiap kriteria yang di miliki oleh suatu permasalahan sehingga di dapat suatu bobot nilai dari kepentingan tiap kriteria - kriteria yang ada, TOPSIS di gunakan untuk mencari solusi yang paling ideal dan kebutuhan masalah yang ada begitupun dengan penelitian yang akan penulis lakukan setiap ketentuan tentang pemilihan penerimaan calon mahasiswa akan di berikan bobot nilai sesuai dengan kebutuhan semua ketentuan mengenai pemilihan penerimaan calon mahasiswa beasiswa bidikmisi kemudian metode TOPSIS akan digunakan untuk mengurutkan calon mahasiswa yang memiliki nilai tertinggi sesuai dengan kriteria berdasarkan hasil yang di peroleh menggunakan metode AHP. Hasil dari proses pengimplementasian metode AHP dan TOPSIS dapat mengurutkan calon mahasiswa penerima beasiswa bidikmisi dari nilai terbesar ke nilai yang terkecil

\section{Tinjauan Pustaka}

\subsection{Sistem Pendukung Keputusan}

AHP merupakan suatu model pendukung keputusan yang dikembangkan oleh Thomas L. Saaty. Model pendukung keputusan ini akan menguraikan masalah multi faktor atau multi kriteria yang kompleks menjadi suatu hirarki, menurut Saaty (2000), hirarki didefinisikan sebagai suatu representasi dari sebuah permasalahan yang kompleks dalam suatu struktur multi level dimana level pertama adalah tujuan, yang diikuti level faktor, kriteria, sub kriteria, dan seterusnya ke bawah hingga level terakhir dari alternatif. Dengan hirarki, suatu masalah yang kompleks dapat diuraikan ke dalam kelompok-kelompoknya yang kemudian diatur menjadi suatu bentuk hirarki sehingga permasalahan akan tampak lebih terstruktur dan sistematis

Menurut Turban (2007:138), komponen Sistem Penunjang Keputusan dapat dibangun dari subsistem, yaitu pertama adalah Subsistem Manajemen Data (Data Management Subsystem) yang memasukkan satu database yang berisi data yang relevan untuk situasi dan dikelola oleh perangkat lunak yang disebut Database Management System (DBMS). Subsistem manajemen data dapat diinterkoneksikan dengan data warehouse perusahaan, repository data perusahaan yang relevan untuk pengambilan keputusan.

George M. Marakas (2003:285) juga mengungkapkan bahwa : Sistem pendukung keputusan merupakan sebuah sistem informasi yang menggunakan model keputusan, sebuah database dan sebuah wawasan dari pembuat keputusan dalam sebuah proses pemodelan yang ad hoc dan interaktif untuk mencapai sebuah keputusan yang spesifik oleh seorang pembuat keputusan yang spesifik.

\section{Fungsi dan Tujuan Pengambilan Keputusan}

Pengambilan keputusan sebagai suatu kelanjutan dari cara pemecahan masalah memiliki fungsi sebagai pangkal permulaan dari semua aktifitas manusia yang sadar dan terarah baik secara individual maupun kelompok serta sebagai sesuatu yang bersifat futuristik yang artinya bersangkut paut dengan masa yang akan datang dimana pengaruhnya berlangsung cukup 
lama. Tujuan pengambilan keputusan antara lain tujuan yang bersifat tunggal, terjadi apabila keputusan yang dihasilkan hanya mengangkut satu masalah, artinya jika satu kali diputuskan maka tidak ada kaitannya dengan masalah lain. Selain itu merupakan tujuan yang bersifat ganda, yang terjadi apabila keputusan yang dihasilkan menyangkut lebih dari satu masalah, artinya bahwa satu keputusan yang diambil sekaligus memecahkan dua masalah.

Sistem pendukung keputusan terdiri dari 3 komponen atau subsistem utama antara lain:

1. Subsistem Manajemen Berbasis Pengetahuan Subsistem tersebut mendukung semua subsistem lain atau bertindak langsung sebagai suatu komponen independen dan bersifat opsional.

2. Subsistem Manajemen Basis Data Terdapat beberapa perbedaan antara basis data untuk SPK dan untuk non-SPK. Basis data untuk SPK bersifat lebih kaya, dimana data harus berasal dari luar maupun dalam, karena adanya proses pengambilan keputusan.

3. Subsistem Manajemen Basis Model Salah satu keunggulan SPK adalah kemampuan untuk mengintegrasikan akses data dan model-model keputusan yang dapat dilakukan dengan menambahkan modelmodel keputusan ke dalam sistem informasi yang menggunakan database sebagai mekanisme integrasi dan komunikasi.

Kemampuan yang dimiliki subsistem basis model antara lain :

a. Kemampuan untuk menciptakan model modelbaru secara cepat dan mudah

b. Kemampuan untuk mengakses dan mengintegrasikan model-model keputusan.

c. Kemampuan untuk mengelola basis model dengan fungsi manajemen yang analog dan manajemen database.

Kemampuan yang harus dimiliki SPK untuk mendukung dialog pemakai atau sistem antara lain :

a. Kemampuan menangani berbagai variasi dialog sesuai dengan pilihan pemakai.

b. Kemampuan mengakomodasikan tindakan pemakai dengan berbagai masukan.

c. Kemampuan menampilkan data dengan berbagai variasi format dan output.

d. Kemampuan memberikan dukungan yang fleksibel untuk mengetahui basis pengetahuan.

\subsection{Metode Analytical Hierarchy Process (AHP)}

AHP merupakan suatu model pendukung keputusan yang dikembangkan oleh Thomas L. Saaty. Model pendukung keputusan ini akan menguraikan masalah multi faktor atau multi kriteria yang kompleks menjadi suatu hirarki, menurut Saaty (2000), hirarki didefinisikan sebagai suatu representasi dari sebuah permasalahan yang kompleks dalam suatu struktur multi level dimana level pertama adalah tujuan, yang diikuti level faktor, kriteria, sub kriteria, dan seterusnya ke bawah hingga level terakhir dari alternatif. Dengan hirarki, suatu masalah yang kompleks dapat diuraikan ke dalam kelompok-kelompoknya yang kemudian diatur menjadi suatu bentuk hirarki sehingga permasalahan akan tampak lebih terstruktur dan sistematis 
AHP sering digunakan sebagai metode pemecahan masalah dibanding dengan metode yang lain karena alasan-alasan sebagai berikut :

a. Struktur yang berhirarki, sebagai konsekuesi dari kriteria yang dipilih, sampai pada subkriteria yang paling dalam.

b. Memperhitungkan validitas sampai dengan batas toleransi inkonsistensi berbagai kriteria dan alternatif yang dipilih oleh pengambil keputusan.

c. Memperhitungkan daya tahan output analisis sensitivitas pengambilan keputusan.

Dalam metode AHP dilakukan langkah-langkah sebagai berikut:

1. Mendefinisikan masalah dan menentukan solusi yang diinginkan. Dalam tahap ini kita berusaha menentukan masalah yang akan kita pecahkan secara jelas, detail dan mudah dipahami. Dari masalah yang ada kita coba tentukan solusi yang mungkin cocok bagi masalah tersebut. Solusi dari masalah mungkin berjumlah lebih dari satu. Solusi tersebut nantinya kita kembangkan lebih lanjut dalam tahap berikutnya.

2. Membuat struktur hierarki yang diawali dengan tujuan utama. Setelah menyusun tujuan utama sebagai level teratas akan disusun level hirarki yang berada di bawahnya yaitu kriteria-kriteria yang cocok untuk mempertimbangkan atau menilai alternatif yang kita berikan dan menentukan alternatif tersebut. Tiap kriteria mempunyai intensitas yang berbeda-beda. Hirarki dilanjutkan dengan subkriteria (jika mungkin diperlukan).

3. Membuat matrik perbandingan berpasangan yang menggambarkan kontribusi relatif atau pengaruh setiap elemen terhadap tujuan atau kriteria yang setingkat di atasnya. Matriks yang digunakan bersifat sederhana, memiliki kedudukan kuat untuk kerangka konsistensi, mendapatkan informasi lain yang mungkin dibutuhkan dengan semua perbandingan yang mungkin dan mampu menganalisis kepekaan prioritas secara keseluruhan untuk perubahan pertimbangan. Pendekatan dengan matriks mencerminkan aspek ganda dalam prioritas yaitu mendominasi dan didominasi. Perbandingan dilakukan berdasarkan judgment dari pengambil keputusan dengan menilai tingkat kepentingan suatu elemen dibandingkan elemen lainnya. Untuk memulai proses perbandingan berpasangan dipilih sebuah kriteria dari level paling atas hirarki misalnya $\mathrm{K}$ dan kemudian dari level di bawahnya diambil elemen yang akan dibandingkan misalnya E1,E2,E3,E4,E5.

4. Melakukan Mendefinisikan perbandingan berpasangan sehingga diperoleh jumlah penilaian seluruhnya sebanyak $\mathrm{n} \times[(\mathrm{n}-1) / 2]$ buah, dengan $\mathrm{n}$ adalah banyaknya elemen yang dibandingkan. Hasil perbandingan dari masing-masing elemen akan berupa angka dari 1 sampai 9 yang menunjukkan perbandingan tingkat kepentingan suatu elemen. Apabila suatu elemen dalam matriks dibandingkan dengan dirinya sendiri maka hasil perbandingan diberi nilai 1. Skala 9 telah terbukti dapat diterima dan bisa membedakan intensitas antar elemen. Hasil perbandingan tersebut diisikan pada sel yang bersesuaian dengan elemen yang dibandingkan. Skala perbandingan perbandingan berpasangan dan maknanya yang diperkenalkan oleh Saaty bisa dilihat di bawah. Intensitas Kepentingan 1 = Kedua elemen sama pentingnya, Dua elemen mempunyai pengaruh yang sama besar $3=$ Elemen yang satu sedikit lebih penting daripada elemen yanga lainnya, Pengalaman dan penilaian sedikit menyokong satu elemen dibandingkan elemen yang lainnya 5 = Elemen yang satu lebih penting daripada yang lainnya, Pengalaman dan penilaian sangat kuat menyokong satu 
elemen dibandingkan elemen yang lainnya 7 = Satu elemen jelas lebih mutlak penting daripada elemen lainnya, Satu elemen yang kuat disokong dan dominan terlihat dalam praktek. 9 = Satu elemen mutlak penting daripada elemen lainnya, Bukti yang mendukung elemen yang satu terhadap elemen lain memeliki tingkat penegasan tertinggi yang mungkin menguatkan. 2,4,6,8 = Nilai-nilai antara dua nilai pertimbangan-pertimbangan yang berdekatan, Nilai ini diberikan bila ada dua kompromi di antara 2 pilihan Kebalikan = Jika untuk aktivitas $\mathrm{i}$ mendapat satu angka dibanding dengan aktivitas $\mathrm{j}$, maka $\mathrm{j}$ mempunyai nilai kebalikannya dibanding dengan $\mathrm{i}$

5. Menghitung nilai eigen dan menguji konsistensinya. Jika tidak konsisten maka pengambilan data diulangi.

6. Mengulangi langkah 3,4, dan 5 untuk seluruh tingkat hirarki.

7. Menghitung vektor eigen dari setiap matriks perbandingan berpasangan yang merupakan bobot setiap elemen untuk penentuan prioritas elemen-elemen pada tingkat hirarki terendah sampai mencapai tujuan. Penghitungan dilakukan lewat cara menjumlahkan nilai setiap kolom dari matriks, membagi setiap nilai dari kolom dengan total kolom yang bersangkutan untuk memperoleh normalisasi matriks, dan menjumlahkan nilai-nilai dari setiap baris dan membaginya dengan jumlah elemen untuk mendapatkan rata-rata.

8. Memeriksa konsistensi hirarki. Yang diukur dalam AHP adalah rasio konsistensi dengan melihat index konsistensi. Konsistensi yang diharapkan adalah yang mendekati sempurna agar menghasilkan keputusan yang mendekati valid. Walaupun sulit untuk mencapai yang sempurna, rasio konsistensi diharapkan kurang dari atau sama dengan $10 \%$.

\subsection{Technique for Order Preference by Similarity to Order Solution (TOPSIS)}

TOPSIS adalah salah satu metode pengambilan keputusan multikriteria atau alternatif pilihan yang merupakan alternatif yang mempunyai jarak terkecil dari solusi ideal positif dan jarak terbesar dari solusi ideal negatif dari sudut pandang geometris dengan menggunakan jarak Euclidean. Namun, alternatif yang mempunyai jarak terkecil dari solusi ideal positif, tidak harus mempunyai jarak terbesar dari solusi ideal negatif. Maka dari itu, TOPSIS mempetimbangkan keduanya, jarak terhadap solusi ideal positif dan jarak terhadap solusi ideal negatif secara bersamaan. Solusi optimal dalam metode TOPSIS didapat dengan menentukan kedekatan relatif suatu altenatif terhadap solusi ideal positif. TOPSIS akan merangking alternatif berdasarkan prioritas nilai kedekatan relatif suatu alternatif terhadap solusi ideal positif. Alternatif-alternatif yang telah dirangking kemudian dijadikan sebagai referensi bagi pengambil keputusan untuk memilih solusi terbaik yang diinginkan.

TOPSIS telah digunakan dalam banyak aplikasi termasuk keputusan investasi keuangan, perbandingan performansi dari perusahaan, pebandingan dalam suatu industri khusus, pemilihan sistem operasi, evaluasi pelanggan, dan perancangan robot.

\section{Langkah langkah metode TOPSIS}

Berikut adalah langkah-langkah dari metode TOPSIS:

1. Membangun sebuah matriks keputusan. 
Matriks keputusan $\mathrm{X}$ mengacu terhadap $\mathrm{m}$ alternatif yang akan dievaluasi berdasarkan $\mathrm{n}$ kriteria. Matriks keputusan X dapat dilihat sebagai berikut:

$$
\begin{aligned}
& \begin{array}{llllll}
x_{1} & x_{2} & x_{3} & \cdots & x_{n}
\end{array}
\end{aligned}
$$

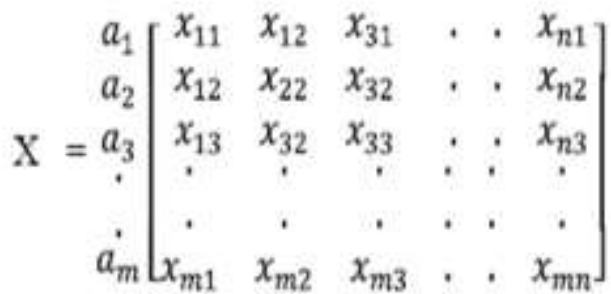

keterangan:

$(\mathrm{i}=1,2,3, \ldots, \mathrm{m})$ adalah alternatif-alternatif yang mungkin,

$(\mathrm{j}=1,2,3, \ldots, \mathrm{n})$ adalah atribut dimana performansi alternatif diukur,adalah performansi alternatif ai dengan acuan atribut $x j$.

2.Membuat matriks keputusan yang ternormalisasi.

Persamaan yang digunakan untuk mentransformasikan setiap elemen xij adalah:

$$
r_{i j}=\frac{x_{i j}}{\sqrt{\sum_{i=1}^{m} x_{i j}^{2}}}
$$

keterangan:

$\mathrm{r}_{i j}$ adalah elemen dari matriks keputusan yang ternormalisasi $\mathrm{R}$, $x_{i j}$ adalah elemen dari matriks keputusan $\mathrm{X}$.

3. Membuat matriks keputusan yang ternormalisasi tebobot.

Dengan bobot $=(,, \ldots$,$) , dimana adalah bobot dari kriteria ke-j dan =1$, maka normalisasi bobot matriks $\mathrm{V}$ adalah:

dengan $\mathrm{i}=1,2,3, \ldots, \mathrm{m} ;$ dan $\mathrm{j}=1,2,3, \ldots, \mathrm{n}$

$$
v_{i j}=\boldsymbol{w}_{j} \boldsymbol{r}_{i j}
$$

keterangan:

$\mathrm{V}_{\mathrm{ij}}$ adalah elemen dari matriks keputusan yang ternormalisai terbobot $\mathrm{V}$,

$\mathrm{W}_{\mathrm{j}}$ adalah bobot kriteria ke-j

$\mathrm{r}_{\mathrm{ij}}$ adalah elemen dari matriks keputusan yang ternormalisasi $\mathrm{R}$. 
4. Menentukan matriks solusi ideal positif dan solusi ideal negatif.Solusi ideal positif dinotasikan, sedangkan solusi ideal negatif dinotasikan . Berikut ini adalah persamaan dari dan :

a. $=\left\{(\max \mid j \in J),\left(\min \mid j \in J^{\prime}\right), i=1,2,3, \ldots, m\right\}(2.4)$

$,,, \ldots$,

$$
\begin{aligned}
A^{+} & =\left\{\left(\max v_{i j} \mid \mathrm{j} \in \mathrm{J}\right),\left(\min v_{i j} \mid \mathrm{j} \in \mathrm{J}^{\prime}\right), \mathrm{i}=1,2,3, \ldots, \mathrm{m}\right\} \\
& =\left\{v_{1}^{-}, v_{2}^{-}, v_{3}^{-}, \ldots, v_{n}^{-}\right\} \\
A^{-} & =\left\{\left(\min v_{i j} \mid \mathrm{j} \in \mathrm{J}\right),\left(\max v_{i j} \mid \mathrm{j} \in \mathrm{J} '\right), \mathrm{i}=1,2,3, \ldots, \mathrm{m}\right\} \\
& =\left\{v_{1}^{-}, v_{2}^{-}, v_{3}^{-}, \ldots, v_{n}^{-}\right\}
\end{aligned}
$$

$\mathbf{J}=\{\mathrm{j}=1,2,3, \ldots, \mathrm{n}$ dan $\mathbf{J}$ merupakan himpunan kriteria keuntungan (benefit criteria) $\}$.

$\mathrm{J}^{\prime}=\left\{\mathrm{j}=1,2,3, \ldots, \mathrm{n}\right.$ dan $\mathrm{J}^{\prime}$ merupakan himpunan kriteria biaya (cost criteria) $\}$

\section{keterangan:}

adalah elemen dari matriks keputusan yang ternormalisasi terbobot $\mathrm{V}$, $(\mathrm{j}=1,2,3, \ldots, \mathrm{n})$ adalah elemen matriks solusi ideal positif, $=(\mathrm{j}=1,2,3, \ldots, \mathrm{n})$ adalah elemen matriks solusi ideal negatif.

\section{Menghitung separasi}

$$
\begin{aligned}
& S^{+} \text {adalah jarak altemative dari solusi ideal positif didefenisikan sebagai: } \\
& s_{i}^{+}=\sqrt{\sum_{j=1}^{n}\left(v_{i j-v_{j}^{+}}\right)^{2}} \text {, dengan } \mathrm{i}=1,2,3, \ldots, \mathrm{m}
\end{aligned}
$$

\section{$S^{\sim}$ adalah jarak altemative dari solusi ideal negative didefenisikan sebagai:}

$$
s_{i}^{-}=\sqrt{\sum_{i=i}^{n}\left(v_{i j-v_{i}^{-}}\right)^{2}} \text {, dengan } \mathrm{i}=1,2,3, \ldots, \mathrm{m}
$$

keterangan:

$S_{i}^{+}$adalah jarak alternative ke-I dari solusi ideal positif, Universitas Sumatera Utara

$S_{i}$-adalah jarak alternative ke-I dari solusi ideal negatif,

$V_{i j}$ adalah elemen dari matriks keputusan yang ternormalisasi terbobot $\mathrm{V}$,

$V_{j}^{+}$adalah elemen matriks solusi ideal positif,

$V_{j}$ adalah elemen matriks solusi ideal negatif. 
6.Menghitung kedekaan terhadap solusi ideal positif.

Kedekatan relatif dari setiap alternative terhadap solusi ideal positif dapat dihitung dengan menggunakan persamaan berikut:

$$
c_{i}^{+}=\frac{s_{i}^{-}}{\left(s_{i}^{-}+s_{i}^{+}\right)}, 0 \leq c_{i}^{+} \leq 1,
$$

dengan $1=1,2,3, \ldots, \mathrm{m}$

keterangan:

$\mathrm{C}_{\mathrm{i}}^{+}$adalah kedekatan relatif dari alternative ke-I tehadap solusi ideal positif,

$\mathrm{S}_{\mathrm{i}}{ }^{+}$adalah jarak alternatif ke-I dari solusi ideal positif,

$\mathrm{S}_{\mathrm{i}}{ }^{-}$adalah jarak alternative ke-I dari solusi ideal negative

7. Merangking aternatif.

Alternative diurutkan dari nilai $\mathrm{C}+$ terbear ke nilai terkecil. Alternatif dengan nilai $\mathrm{C}+$ terbesar merupakan solusi terbaik.

\subsection{Beasiswa Bidikmisi}

Program Bidikmisi merupakan salah satu program unggulan pemerintah yang pelaksanaannya sudah dimulai sejak tahun 2010, sampai dengan tahun 2016 ini tercatat lebih dari 352 ribu mahasiswa yang telah memperoleh Bantuan Biaya Pendidikan Bidikmisi, dari jumlah tersebut sebanyak 87 ribu telah menyelesaikan pendidikannya. Jumlah peminat Program Bidikmisi menunjukkan peningkatan yang sangat signifikan dari tahun ke tahun, untuk tahun 2016 tercatat sebanyak 416.428 pelamar tetapi hanya sekitar 75.000 saja yang bisa diakomodir karena keterbatasan anggaran pemerintah.

Menurut Pedoman Bantuan Biaya Pendidikan Bidikmisi yang dikeluarkan oleh Direktorat Jenderal Pembelajaran dan Kemahasiswaan, Kementrian Riset Teknologi dan Pendidikan Tinggi (kemenristekdikti) persyaratan untuk mendaftar tahun 2017 adalah sebagai berikut :

1. Siswa SMA/SMK/MA atau bentuk lain yang sederajat yang akan lulus pada tahun 2017;

2. Lulusan tahun 2016 yang bukan penerima Bidikmisi dan tidak bertentangan dengan ketentuan penerimaan mahasiswa baru di masing-masing perguruan tinggi;

3. Usia paling tinggi pada saat mendaftar adalah 21 tahun;

4. Tidak mampu secara ekonomi dengan kriteria: a. Siswa penerima Beasiswa Siswa Miskin (BSM) atau Pemegang Kartu Indonesia Pintar (KIP) atau sejenisnya; atau b. Pendapatan kotor gabungan orang Tua/Wali (suami istri) maksimal sebesar Rp3.000.000,00 per bulan dan atau pendapatan kotor gabungan orangtua/wali dibagi jumlah anggota keluarga maksimal Rp750.000,00 setiap bulannya.

5. Pendidikan orang Tua/Wali setinggi-tingginya S1 (Strata 1) atau Diploma 4;

6. Memiliki potensi akademik baik berdasarkan rekomendasi objektif dan akurat dari Kepala Sekolah;

7. Pendaftar difasilitasi untuk memilih salah satu diantara PTN atau PTS dengan ketentuan: a. PTN dengan pilihan seleksi masuk: 1) Seleksi Masuk Perguruan Tinggi Negeri 
(SNMPTN); 2) Seleksi Bersama Masuk Perguruan Tinggi Negeri (SBMTPN); 3) Seleksi mandiri PTN. b. Politeknik, UT, dan Institut Seni dan Budaya c. PTS sesuai dengan pilihan seleksi masuk.

Sedangkan untuk proses seleksi bagi PTS dijelaskan sebagai berikut :

1. Seleksi ditentukan oleh masing-masing PTS dengan memprioritaskan pendaftar yang mempunyai potensi akademik yang paling tinggi, pendaftar yang paling tidak mampu secara ekonomi, dan memperhatikan asal daerah pendaftar. Untuk memastikan kondisi ekonomi pendaftar, akan lebih baik kalau PTS melakukan kunjungan ke alamat pendaftar;

2. Kunjungan ke alamat pendaftar dapat dilakukan dengan mendayagunakan mahasiswa PTS yang bersangkutan atau PTS dari domisili pendaftar dengan mekanisme yang disetujui bersama;

3. Pelamar Bidikmisi penerima BSM dan/atau memiliki KIP dan sejenisnya dapat dikecualikan dalam proses verifikasi kelayakan ekonomi. Namun, jika di kemudian hari ditemukan ternyata tidak layak dapat dikenai sanksi;

4. Hasil seleksi calon mahasiswa diumumkan oleh panitia seleksi PTS dan diinformasikan ke Ditjen Belmawa melalui Sistem Informasi Manajemen Bidikmisi.

Berdasarkan penjelasan-penjelasan diatas mengenai persyaratan dan proses seleksi program bidikmisi maka kriteria yang ditetapkan untuk sistem pendukung keputusan ini akan disesuaikan dengan persyaratan dan proses seleksi diatas.

\section{Analisis Sistem}

Analisis sistem secara sistematis menilai bagaimana fungsi bisnis dengan cara mengamati proses input dan pengolahan data serta proses output informasi untuk membantu peningkatan proses bisnis.

Untuk menentukan penerimaan calon mahasiswa bidikmisi, pimpinan pergurauan tinggi sebagai pengambil keputusan seringkali hanya menilai dari beberapa kriteria saja. Hal ini tentu menjadi sebuah kekurangan untuk menentukan tepat atau tidaknya calon mahasiswa terpilih menjadi penerima beasiswa bidikmisi. Di samping itu, pengambilan keputusan juga di hadapkan dengan adanya berbagai kriteria yang berpengaruh di dalam penerimaan calon mahasiswa bidikmisi. Sistem yang sedang berjalan masih menggunakan sistem manual dengan prosedur seperti yang di ambarkan pada deskripsi di bawah ini:

1. Universitas membuka pendaftaran penerimaan beasiswa bidikmisi

2. Calon mahasiswa melakukan pendaftaran calon mahasiswa

3. Calon mahasiswa mengikuti tes seleksi penerimaan beasiswa bidikmisi

4. Universitas memeriksa hasil tes dan menentukan calon mahasiswa yang berhak mendapatkan beasiswa bidikmisi secara manual

5. Universitas mengumumkan hasil penerimaan calon mahasiswa yang mendapatkan beasiswa bidikmisi 


\section{Perhitungan Metode AHP}

Perhitungan AHP untuk menetukan tiap-tiap bobot (TPV) kriteria dan subkriteria, serta menetukan rasio konsistensi diterima atau tidaknya kriteria dan subkriteria.

Perhitungan AHP dapat digambarkan pada flowchart di bawah ini:

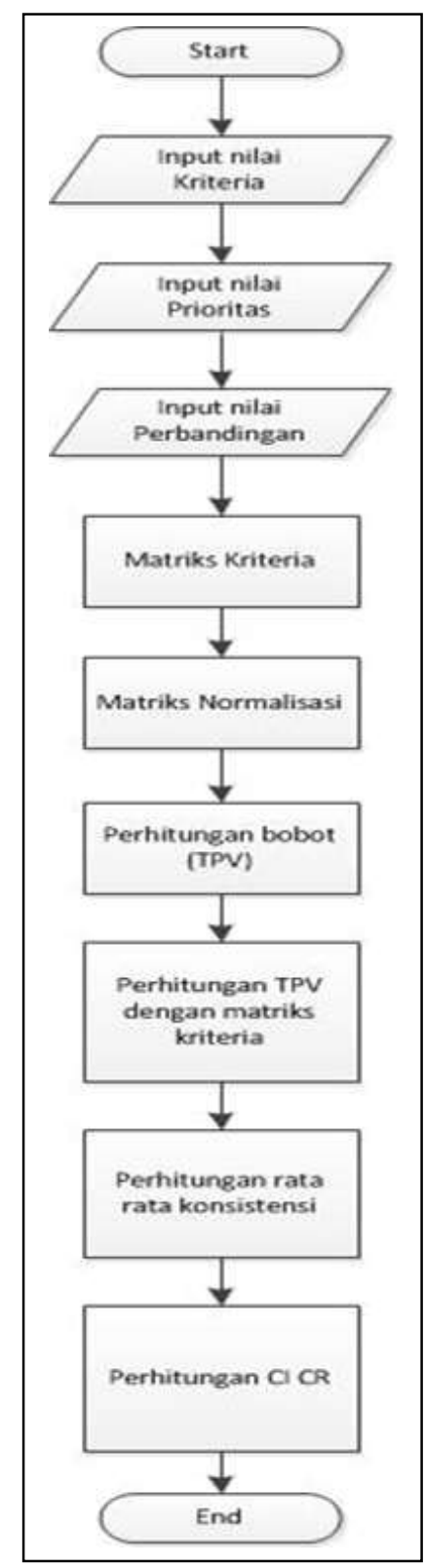

Gambar 3.1 Flowchart Perhitungan AHP

Adapun langkah-langkah perhitungan AHP seperti di bawah ini:

1. Menetukan matriks berpasangan untuk kriteria penerimaan calon mahasiswa bidikmisi. 
Tabel 3.1 Tabel Matriks Berpasangan AHP

\begin{tabular}{|l|r|r|r|r|r|}
\hline & $\begin{array}{c}\text { Pemegang } \\
\text { KIP atau } \\
\text { BSM }\end{array}$ & $\begin{array}{c}\text { Penghasilan } \\
\text { Orang Tua }\end{array}$ & $\begin{array}{c}\text { Pendidikan } \\
\text { Orang Tua }\end{array}$ & $\begin{array}{c}\text { Prestasi } \\
\text { Akademik }\end{array}$ & $\begin{array}{c}\text { Non } \\
\text { Akademik }\end{array}$ \\
\hline $\begin{array}{l}\text { Pemegang KIP atau } \\
\text { BSM }\end{array}$ & 1.00 & 2.00 & 2.00 & 3.00 & 2.00 \\
\hline $\begin{array}{l}\text { Penghasilan Orang } \\
\text { Tua }\end{array}$ & 0.50 & 1.00 & 2.00 & 3.00 & 2.00 \\
\hline $\begin{array}{l}\text { Pendidikan Orang } \\
\text { Tua }\end{array}$ & 0.50 & 0.50 & 1.00 & 2.00 & 3.00 \\
\hline Prestasi Akademik & 0.33 & 0.33 & 0.50 & 1.00 & 3.00 \\
\hline $\begin{array}{l}\text { Prestasi Non } \\
\text { Akademik }\end{array}$ & 0.50 & 0.50 & 0.33 & 0.33 & 1.00 \\
\hline Jumlah Kolom & 2.83 & 4.33 & 5.83 & 9.33 & 11.00 \\
\hline
\end{tabular}

2. Menghitung matriks normalisasi yaitu membagi setiap elemen pada kolom dengan jumlah per kolom yang sesuai

Tabel 3.2 Tabel Matriks Normalisasi AHP

\begin{tabular}{|l|r|r|r|r|r|r|}
\hline & $\begin{array}{c}\text { Pemegan } \\
\text { g KIP } \\
\text { atau BSM }\end{array}$ & $\begin{array}{c}\text { Penghasila } \\
\text { n Orang } \\
\text { Tua }\end{array}$ & $\begin{array}{c}\text { Pendidika } \\
\text { n Orang } \\
\text { Tua }\end{array}$ & $\begin{array}{c}\text { Prestasi } \\
\text { Akademi } \\
\mathrm{k}\end{array}$ & $\begin{array}{c}\text { Prestasi } \\
\text { Non } \\
\text { Akademi } \\
\mathrm{k}\end{array}$ & $\begin{array}{c}\text { Jumla } \\
\mathrm{h} \\
\text { Baris }\end{array}$ \\
\hline $\begin{array}{l}\text { Pemegang KIP atau } \\
\text { BSM }\end{array}$ & 0.35 & 0.46 & 0.34 & 0.32 & 0.18 & 1.48 \\
\hline $\begin{array}{l}\text { Penghasilan Orang } \\
\text { Tua }\end{array}$ & 0.18 & 0.23 & 0.34 & 0.32 & 0.18 & 1.07 \\
\hline $\begin{array}{l}\text { Pendidikan Orang } \\
\text { Tua }\end{array}$ & 0.18 & 0.12 & 0.17 & 0.21 & 0.27 & 0.68 \\
\hline Prestasi Akademik & 0.12 & 0.08 & 0.09 & 0.11 & 0.27 & 0.39 \\
\hline $\begin{array}{l}\text { Prestasi Non } \\
\text { Akademik }\end{array}$ & 0.18 & 0.12 & 0.06 & 0.04 & 0.09 & 0.38 \\
\hline
\end{tabular}

3. Membagi jumlah baris dengan jumlah kriteria yaitu (6) sehingga menghasilkan TPV.

Tabel 3.3 Tabel Pembobotan (TPV)

\begin{tabular}{|l|c|}
\hline Kriteria & TPV (Bobot) \\
\hline $\begin{array}{l}\text { Pemegang KIP atau } \\
\text { BSM }\end{array}$ & 0.33 \\
\hline $\begin{array}{l}\text { Penghasilan Orang } \\
\text { Tua }\end{array}$ & 0.25 \\
\hline Pendidikan Orang & 0.19 \\
\hline
\end{tabular}




\begin{tabular}{|l|c|} 
Tua & \\
\hline Prestasi Akademik & 0.13 \\
\hline $\begin{array}{l}\text { Prestasi Non } \\
\text { Akademik }\end{array}$ & 0.10 \\
\hline
\end{tabular}

4. Selanjutnya perkalian TPV dengan nilai perbandingan matriks kriteria yang di jumlahkan tiap baris.

Tabel 3.4 Tabel Perkalian TPV dengan Matriks Kriteria

\begin{tabular}{|c|c|c|c|c|c|c|c|}
\hline & $\begin{array}{c}\text { Pemegan } \\
\text { g KIP } \\
\text { atau } \\
\text { BSM }\end{array}$ & $\begin{array}{c}\text { Penghasil } \\
\text { an Orang } \\
\text { Tua }\end{array}$ & $\begin{array}{c}\text { Pendidik } \\
\text { an Orang } \\
\text { Tua }\end{array}$ & $\begin{array}{c}\text { Prestasi } \\
\text { Akademi } \\
\text { k }\end{array}$ & $\begin{array}{l}\text { Prestasi } \\
\text { Non } \\
\text { Akademi } \\
\text { k }\end{array}$ & $\begin{array}{c}\text { Jumlah } \\
\text { Baris }\end{array}$ & $\begin{array}{c}\text { Jumlah } \\
\text { Baris/TP } \\
\text { V }\end{array}$ \\
\hline $\begin{array}{l}\text { Pemegan } \\
\text { g KIP } \\
\text { atau BSM }\end{array}$ & $\begin{array}{r}0.332116 \\
707\end{array}$ & $\begin{array}{r}0.501337 \\
486\end{array}$ & $\begin{array}{r}0.380118 \\
705\end{array}$ & $\begin{array}{r}0.396092 \\
731\end{array}$ & $\begin{array}{r}0.190248 \\
575\end{array}$ & $\begin{array}{r}1.799914 \\
203\end{array}$ & $\begin{array}{r}5.41952 \\
322\end{array}$ \\
\hline $\begin{array}{l}\text { Penghasil } \\
\text { an Orang } \\
\text { Tua }\end{array}$ & $\begin{array}{r}0.166058 \\
353\end{array}$ & $\begin{array}{r}0.250668 \\
743\end{array}$ & $\begin{array}{r}0.380118 \\
705\end{array}$ & $\begin{array}{r}0.396092 \\
731\end{array}$ & $\begin{array}{r}0.190248 \\
575\end{array}$ & $\begin{array}{r}1.383187 \\
107\end{array}$ & $\begin{array}{r}5.51798 \\
796\end{array}$ \\
\hline $\begin{array}{l}\text { Pendidika } \\
\text { n Orang } \\
\text { Tua }\end{array}$ & $\begin{array}{r}0.166058 \\
353\end{array}$ & $\begin{array}{r}0.125334 \\
372\end{array}$ & $\begin{array}{r}0.190059 \\
352\end{array}$ & $\begin{array}{r}0.264061 \\
821\end{array}$ & $\begin{array}{r}0.285372 \\
862\end{array}$ & $\begin{array}{r}1.030886 \\
76\end{array}$ & $\begin{array}{r}5.42402 \\
543\end{array}$ \\
\hline $\begin{array}{l}\text { Prestasi } \\
\text { Akademi } \\
\mathrm{k}\end{array}$ & $\begin{array}{r}0.110705 \\
569\end{array}$ & $\begin{array}{r}0.083556 \\
248\end{array}$ & $\begin{array}{r}0.095029 \\
676\end{array}$ & $\begin{array}{r}0.132030 \\
91\end{array}$ & $\begin{array}{r}0.285372 \\
862\end{array}$ & $\begin{array}{r}0.706695 \\
266\end{array}$ & $\begin{array}{r}5.35249 \\
862\end{array}$ \\
\hline $\begin{array}{l}\text { Prestasi } \\
\text { Non } \\
\text { Akademi } \\
\text { k }\end{array}$ & $\begin{array}{r}0.166058 \\
353\end{array}$ & $\begin{array}{r}0.125334 \\
372\end{array}$ & $\begin{array}{r}0.063353 \\
117\end{array}$ & $\begin{array}{r}0.044010 \\
303\end{array}$ & $\begin{array}{r}0.095124 \\
287\end{array}$ & $\begin{array}{r}0.493880 \\
433\end{array}$ & $\begin{array}{r}5.19194 \\
883\end{array}$ \\
\hline
\end{tabular}

5. Kemudian pembagi antara kolom baris dengan jumlah kolom baris dengan TVP mendapatkan $\chi$ maks,Sehingga mendapatkan $\chi$ maks $=5.381196813$

6. Setelah mendapatkan $\chi$ maks, kemudian mencari Consistency Indeks (CI)

$\mathrm{CI}=(\chi$ maks-n $) /(\mathrm{n}-1)$

$\mathrm{CI}=0.095299203$

7. Kemudian mencari consitency ratio (CR) dengan mengacu pada nilai indeks random atau random index (RI) yang dapat di ambil dengan ketentuan sesuai dengan jumlah kriteria yang di ambil,

$\mathrm{CR}=\underline{0.095299203}$

1.12

$=0.085088574$

1.12 di dapatkan dari nilai jumlah kriteria pada tabel IR 
Tabel 3.5 Tabel Inconsistency Ratio(IR)

\begin{tabular}{|l|l|l|l|l|l|l|l|l|l|l|l|l|l|l|}
\hline 1 & 2 & 3 & 4 & 5 & 6 & 7 & 8 & 9 & 10 & 11 & 12 & 13 & 14 & 15 \\
\hline 0 & 0 & 0,58 & 0,9 & 1,12 & 1,24 & 1,32 & 1,41 & 1,45 & 1,49 & 1,51 & 1,48 & 1,56 & 1,157 & 0,159 \\
\hline
\end{tabular}

\section{Perhitungan Metode TOPSIS}

Setelah nilai TPV kriteria dan TPV subkriteria sudah di dapat dan masing-masing menunjukan konsistensi yang baik, kemudian menghitung matriks keputusan, seperti pada flowchart di bawah ini :

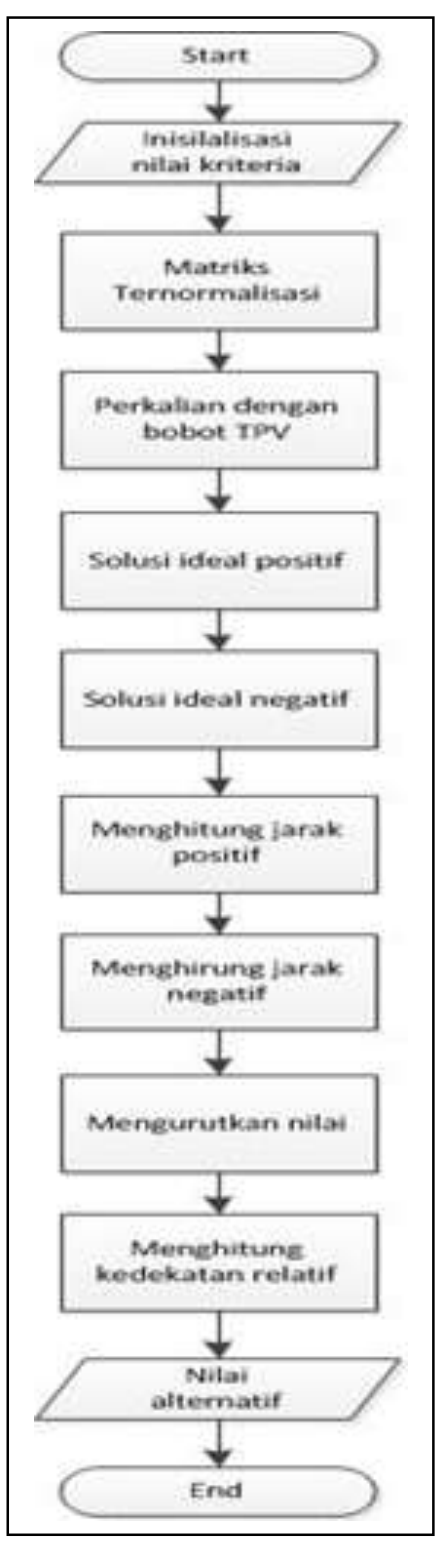

Gambar 3.2 Flowchat Pehitungan TOPSIS

Contoh data alternatif yang ada pada sistem yang sudah di tentukan oleh bagian penerimaan mahasiswa baru. 
Tabel 3.6 Tabel Alternatif TOPSIS

\begin{tabular}{|l|r|l|l|l|r|}
\hline Alternatif & $\begin{array}{l}\text { Pemegang } \\
\text { KIP atau } \\
\text { BSM }\end{array}$ & $\begin{array}{l}\text { Penghasilan } \\
\text { Orang Tua }\end{array}$ & $\begin{array}{l}\text { Pendidikan } \\
\text { Orang Tua }\end{array}$ & $\begin{array}{l}\text { Prestasi } \\
\text { Akademik }\end{array}$ & $\begin{array}{l}\text { Prestasi } \\
\text { Non } \\
\text { Akademik }\end{array}$ \\
\hline Siswa 1 & 2 & 1250000 & SD & 81 & 0 \\
\hline Siswa 2 & 1 & 900000 & SD & 86 & 1 \\
\hline Siswa 3 & 2 & 750000 & SMP & 78 & 0 \\
\hline Siswa 4 & 0 & 2100000 & SD & 87 & 2 \\
\hline
\end{tabular}

1. Mengkonversi data alternative dengan beban di bawah ini

Tabel 3.7 Tabel Konversi Alternatif TOPSIS

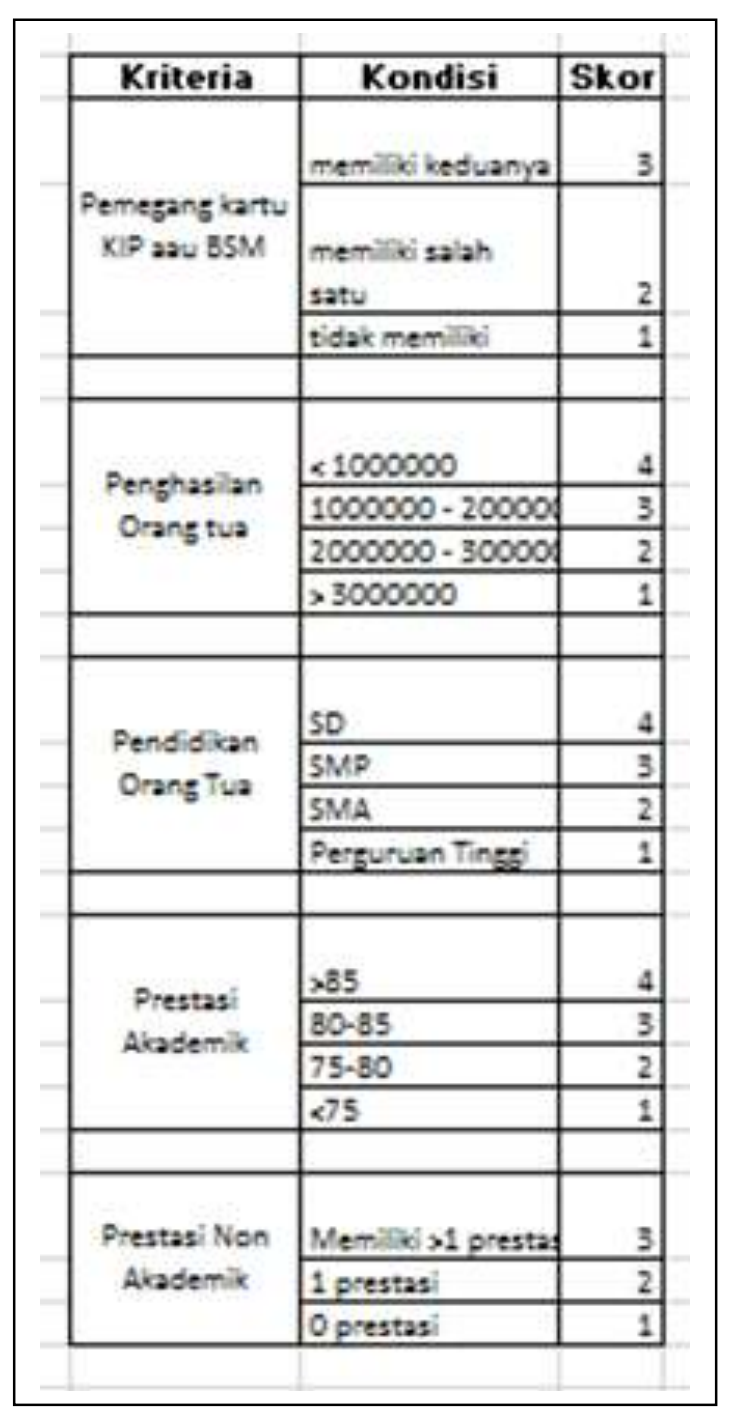

8. Membuat tabel konversi sesuai dengan data alternative di atas 
Tabel 3.8 Tabel Konversi Alternatif TOPSIS

\begin{tabular}{|l|l|l|r|l|l|}
\hline Hasil Konversi & $\begin{array}{l}\text { Pemegang } \\
\text { KIP atau } \\
\text { ASM }\end{array}$ & $\begin{array}{l}\text { Penghasilan } \\
\text { Orang Tua }\end{array}$ & $\begin{array}{l}\text { Pendidikan } \\
\text { Orang Tua }\end{array}$ & $\begin{array}{l}\text { Prestasi } \\
\text { Akademik }\end{array}$ & $\begin{array}{l}\text { Prestasi } \\
\text { Non } \\
\text { Akademik }\end{array}$ \\
\hline Siswa 1 & 3 & 3 & 4 & 3 & 1 \\
\hline Siswa 2 & 2 & 3 & 4 & 4 & 2 \\
\hline Siswa 3 & 3 & 3 & 3 & 2 & 2 \\
\hline Siswa 4 & 1 & 2 & 4 & 4 & 3 \\
\hline Jumlah & 9 & 11 & 15 & 13 & 7 \\
\hline
\end{tabular}

2. Membuat matriks keputusan yang ternormalisasi

Tabel 3.9 Tabel Matriks Keputusan Ternormalisasi

\begin{tabular}{|l|l|l|l|l|l|}
\hline \multicolumn{2}{|l|}{ Matriks Keputusan Ternomalisasi } \\
\hline Alternatif & $\begin{array}{l}\text { Pemegang } \\
\text { KIP atau } \\
\text { BSM }\end{array}$ & $\begin{array}{l}\text { Penghasilan } \\
\text { Orang Tua }\end{array}$ & $\begin{array}{l}\text { Pendidikan } \\
\text { Orang Tua }\end{array}$ & $\begin{array}{l}\text { Prestasi } \\
\text { Akademik }\end{array}$ & $\begin{array}{l}\text { Prestasi } \\
\text { Non } \\
\text { Akademik }\end{array}$ \\
\hline Siswa 1 & 0.3333333 & 0.2727273 & 0.2666667 & 0.2307692 & 0.1428571 \\
\hline Siswa 2 & 0.2222222 & 0.2727273 & 0.2666667 & 0.3076923 & 0.2857143 \\
\hline Siswa 3 & & & & & \\
\hline Siswa 4 & 0.3333333 & 0.2727273 & 0.2 & 0.1538462 & 0.1428571 \\
\hline
\end{tabular}

3. Membuat matriks keputusan ternormalisasi terbobot yang nilainya didapat dari hasil perkalian antara TPV bobot kriteria dengan TPV boot subkriteria.

Tabel 3.10 Tabel perkalian bobot TPV

\begin{tabular}{|l|c|c|c|c|c|c|}
\hline \multicolumn{1}{|c|}{ Miternatif } & $\begin{array}{c}\text { Pemegang } \\
\text { KIP atau } \\
\text { BSM }\end{array}$ & $\begin{array}{c}\text { Penghasilan } \\
\text { Orang Tua }\end{array}$ & $\begin{array}{c}\text { Pendidikan } \\
\text { Orang Tua }\end{array}$ & $\begin{array}{c}\text { Prestasi } \\
\text { Akademik }\end{array}$ & $\begin{array}{c}\text { Prestasi } \\
\text { Non } \\
\text { Akademik }\end{array}$ & Jumlah \\
\hline Siswa 1 & 0.1107056 & 0.0683642 & 0.0506825 & 0.0304687 & 0.0135892 & 0.2738101 \\
\hline Siswa 2 & 0.0738037 & 0.0683642 & 0.0506825 & 0.0406249 & 0.0271784 & 0.2606537 \\
\hline Siswa 3 & 0.1107056 & 0.0683642 & 0.0380119 & 0.0203124 & 0.0135892 & 0.2509833 \\
\hline Siswa 4 & 0.0369019 & 0.0455761 & 0.0506825 & 0.0406249 & 0.0407676 & 0.2145529 \\
\hline
\end{tabular}

4. Selanjutnya menentukan matriks solusi ideal positif (+), yaitu dengan mencari nilai maksimal dari setiap kolom di atas, kecuali kriteria harga mencari nilai minimal.

Tabel 3.11 Tabel Solusi Ideal Posotif

\begin{tabular}{|c|c|c|c|c|c|c|}
\hline \multicolumn{7}{|c|}{ Solusi Ideal Positif } \\
\hline & $\begin{array}{c}\text { Pemegang } \\
\text { KIP atau } \\
\text { BSM }\end{array}$ & $\begin{array}{c}\text { Penghasilan } \\
\text { Orang Tua }\end{array}$ & $\begin{array}{l}\text { Pendidikan } \\
\text { Orang Tua }\end{array}$ & $\begin{array}{l}\text { Prestasi } \\
\text { Akademik: }\end{array}$ & $\begin{array}{c}\text { Prestasi } \\
\text { Non } \\
\text { Akademik }\end{array}$ & Jumlah \\
\hline & Max & Max & Max & Max & Max & \\
\hline At & 0.1107056 & 0.0683642 & 0.0506825 & 0.0406249 & 0.0407676 & 0.3111447 \\
\hline
\end{tabular}

5. Setelah mendapatkan solusi ideal positif dan solusi ideal negative, 
Selanjutnya menghiung jarak alternative solusi ideal positif dengan pengurangan hasil penjumlahan baris solusi ideal posiif dengan penjumlahan baris matriks keputusan ternormalisasi terbobot.

\section{Tabel 3.12 Tabel Solusi Ideal Negatif}

\begin{tabular}{|l|c|c|c|c|c|c|c|}
\hline Solusi Ideal Negatif & $\begin{array}{c}\text { Pemegang } \\
\text { KIP atau } \\
\text { BSM }\end{array}$ & $\begin{array}{c}\text { Penghasilan } \\
\text { Orang Tua }\end{array}$ & $\begin{array}{c}\text { Pendidikan } \\
\text { Orang Tua }\end{array}$ & $\begin{array}{c}\text { Prestasi } \\
\text { Akademik }\end{array}$ & $\begin{array}{c}\text { Prestasi } \\
\text { Non } \\
\text { Akrademik }\end{array}$ & Jumlah \\
\hline A- & Min & Min & Min & Min & Min & \\
\hline & 0.0369019 & 0.0455761 & 0.0380119 & 0.0203124 & 0.0135892 & 0.1543915 \\
\hline
\end{tabular}

6. Menghitung jarak alternatif solusi ideal negatif dengan pengurangan hasil penjumlah baris solusi ideal negative dengan penjumlahan baris matriks keputusan ternormalisasi terbobot.

Tabel 3.13 Tabel Solusi Alternatif

\begin{tabular}{|l|r|r|r|}
\hline \multicolumn{1}{|c|}{ Alternatif } & \multicolumn{1}{c|}{ S+ } & S- & V \\
\hline Siswa 1 & 0.0373346 & -0.1194186 & 1.4548338 \\
\hline Siswa 2 & 0.050491 & -0.1062622 & 1.9053256 \\
\hline Siswa 3 & 0.0601614 & -0.0965918 & 2.6514103 \\
\hline Siswa 4 & 0.0965918 & -0.0601614 & -1.6514103 \\
\hline
\end{tabular}

7. Selanjutnya menghitung kedekatan relatif terhadap solusi ideal posotif.

Tabel 3.14 Tabel Solusi Kedekatan Relatif

\begin{tabular}{|l|r|r|r|}
\hline \multicolumn{1}{|c|}{ Alternatif } & \multicolumn{1}{c|}{ S+ } & S- & V \\
\hline Siswa 1 & 0.0373346 & -0.1194186 & 1.4548338 \\
\hline Siswa 2 & 0.050491 & -0.1062622 & 1.9053256 \\
\hline Siswa 3 & 0.0601614 & -0.0965918 & 2.6514103 \\
\hline Siswa 4 & 0.0965918 & -0.0601614 & -1.6514103 \\
\hline
\end{tabular}

8. Berdasarkan hasil perhitungan kedekatan relative itulah prioritas calon mahasiswa yang terbaik di tentukan yang mana nilai kedekatan relatif yang lebih besar adalah calon mahasiswa yang di sarankan.

\section{Perancangan}

\section{Pemodelan Sistem dengan Use Case}

Pemodelan dengan use case dimana seorang aktor dalam hal ini yaitu panitia penerimaan mahasiswa baru (PPMB) berhubungan dengan sistem yang akan di bangun yaitu sistem pendukung keputusan penerimaan beasiswa bidikmisi. 


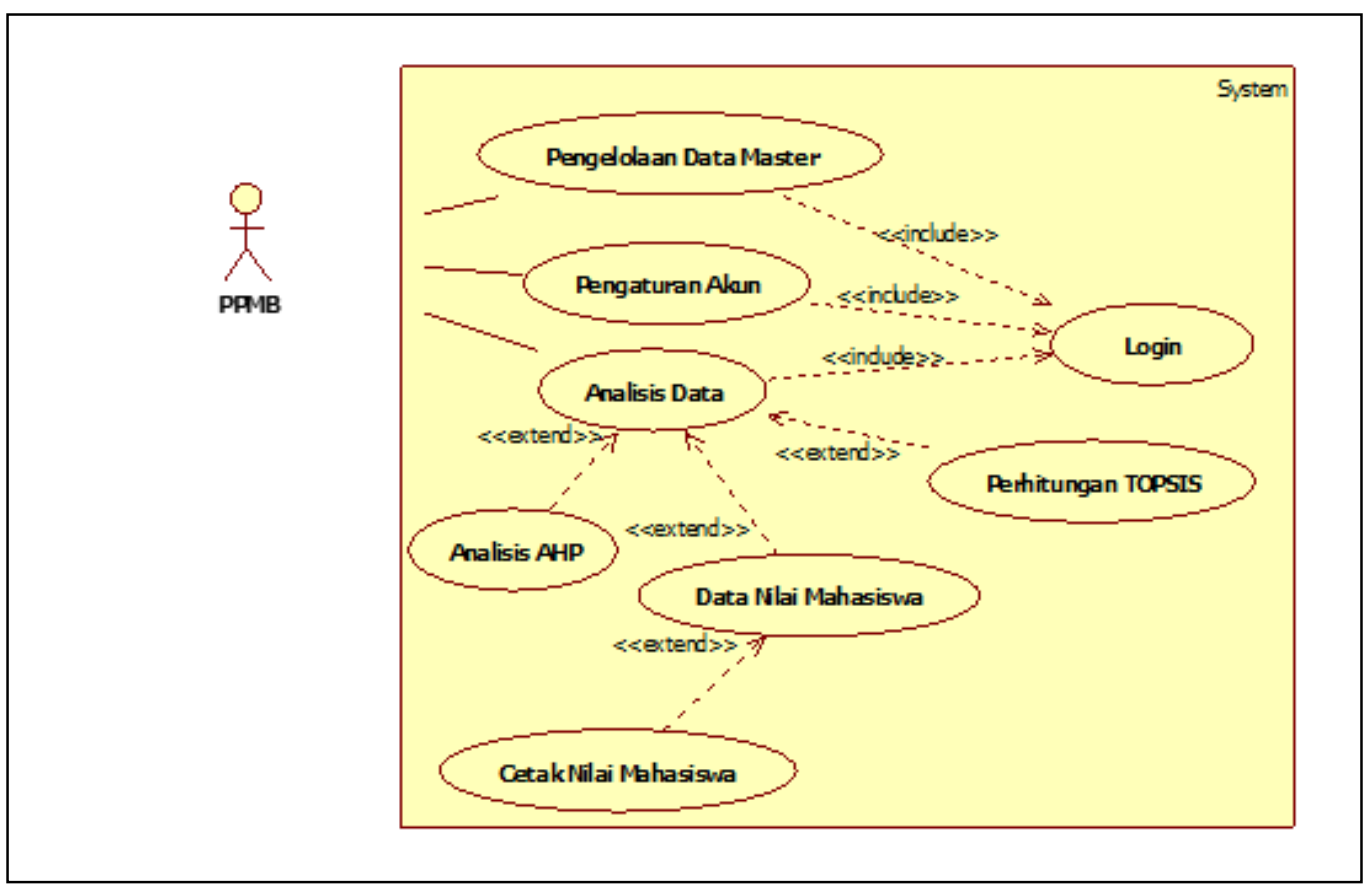

Gambar 4.1 Use Case Sistem pendukung Keputusan Penerimaan Beasiswa Bidikmisi

\section{Activity Diagram Analisis AHP}

Activity Diagram analisis AHP menujukan aktifitas yang dilakukan oleh bagian Panitia Penerimaan Mahasiswa Baru pada saat melakukan analisis data kriteria menggunakan metode AHP.

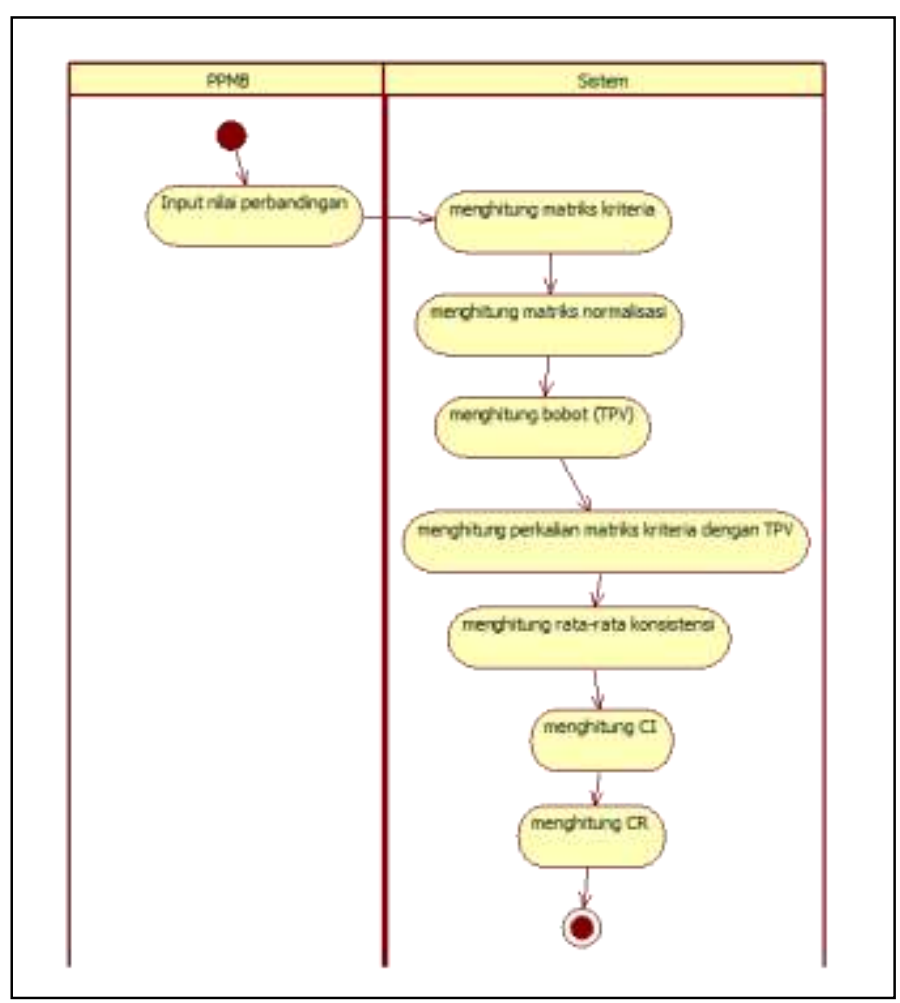

Gambar 4.2 Activity Diagram Analisis AHP 
1. Panitia Penerimaan Mahasiswa Baru memilih menu data analisis kemudian sub menu analisis AHP.

2. Sistem menampilkan form data analisis AHP, pada form tersebut kita dapat menginputkan nilai perbandingan kriteria sesuai dengan kepentingan yang ada pada tabel kriteria pembobotan.

3. Setelah data pembobotan di inputkan ,sistem akan men-genarate hasil perbandingan dari pembobotan tersebut .

4. Setelah itu kita dapat memproses analisis AHP,data matriks perbandingan akan tersimpan otomatis.

5. Apabila kita akan merubah data pembobotan kita dapat menghapus proses analisis sebelumnya dan menginput kembali data analisis.

6. Proses AHP di lakukan oleh sistem.

7. Sehingga muncul tampilan hasil analisis pada form tersebut.

\section{Activity Diagram Perhitungan TOPSIS}

Activity Diagram Perhitungan TOPSIS menujukan aktifitas yang dilakukan oleh bagian Panitia Penerimaan Mahasiswa Baru pada saat melakukan analisis data alternatif menggunakan metode TOPSIS.

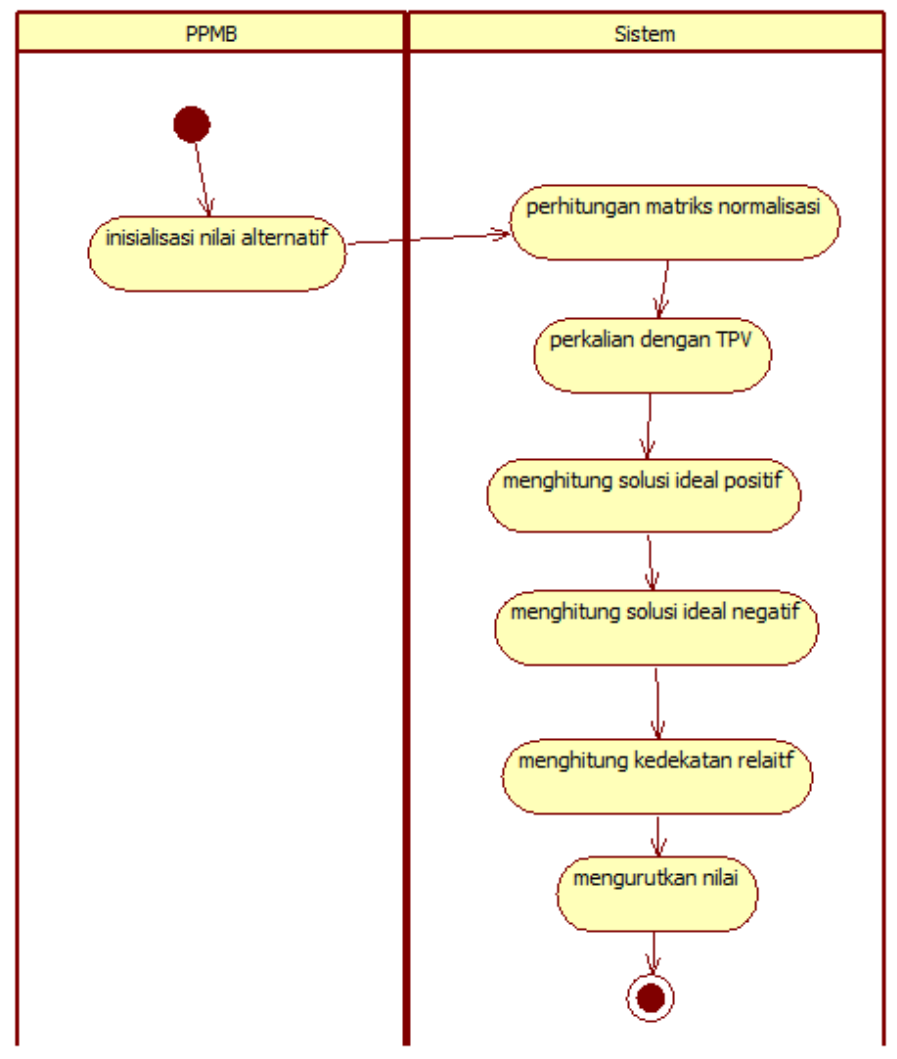

Gambar 4.3 Activity Diagram Perhitungan TOPSIS

1. Panitia Penerimaan Mahasiswa Baru memilih menu data analisis kemudian sub menu perhitungan TOPSIS. 
2. Sistem menampilkan form perhitungan TOPSIS pada form tersebut kita dapat menginputkan nilai alternatif sesuai data yang tersedia.

3. Setelah itu kita dapat memproses perhitungan topsis, dengan data alternative dan bobot yang kita dapatkan melalui analisis AHP.

4. Setelah itu kita dapat menekan tonbol proses analis

5. Sehingga muncul tampilan hasil analisis pada form tersebut.

6. Untuk menyimpan data perhitungan TOPSIS kita dapat menekan tombol simpan yang tersedia pada form tersebut.

\section{Class Diagram}

Class merepresentasikan sesuatu yang di tangani oleh sistem. Untuk memodelkan Class yang akan dibuat, maka digunakan class diagram yang akan menggambarkan class yang di gunakan pada sistem pendukung keputusan penerimaan beasiswa bidikmisi.

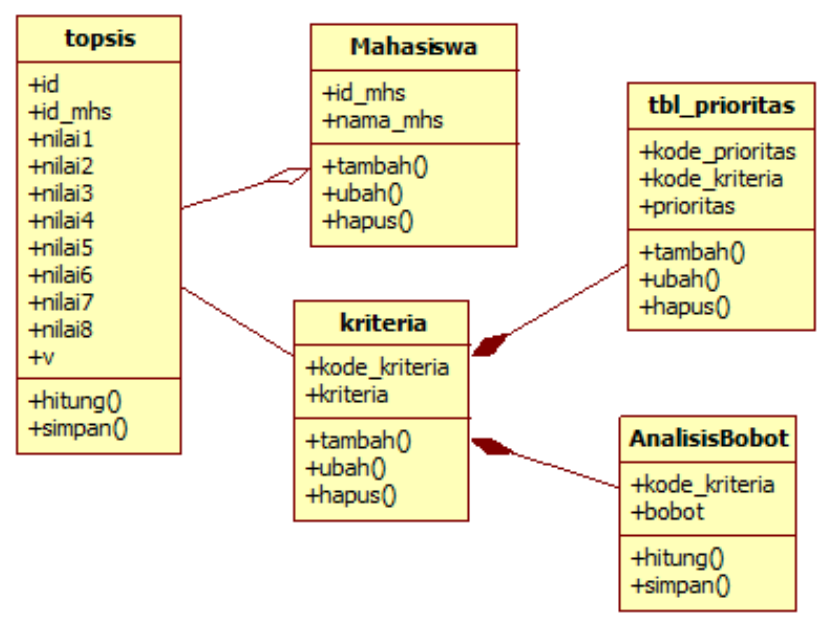

Gambar 4.4 Class Diagram Perhitungan Metode AHP dan TOPSIS

\section{Antarmuka Aplikasi Metode AHP}

Pada menu utama terdapat menu analisis dan sub menu analisis AHP dalam tampilan tersebut kita harus menginputkan nilai dari kriteria yang telah ditentukan sebelumnya pada data master kriteria agar menghasilkan nilai bobot yang kemudian akan dihitung pada perhitungan TOPSIS, pada analisis AHP juga menghasilkan nilai CI yang menetukan apakah data analisis tersebut layak atau tidak layak.

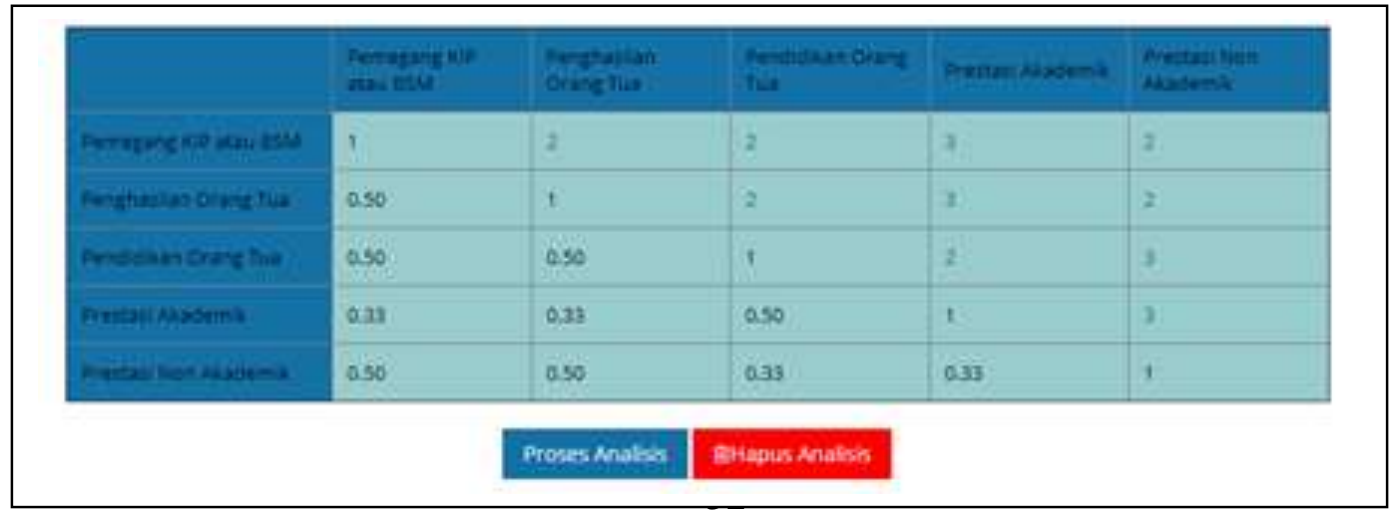




\section{Kesimpulan}

Sistem pendukung keputusan penerimaan calon mahasiswa bidikmisi dapat menyimpan data kriteria, data mahasiswa, data prioritas kriteria, dan menganalisis bobot nilai kriteria serta alternatif mahasiswa dengan menggunakan metode AHP dan TOPSIS, hasil dari analisis tersebut dapat di cetak untuk laporan penerimaan calon mahasiswa bidikmisi. Metode AHP dan TOPSIS dapat menentukan alternatif mahasiswa terbaik hal ini terbukti dengan mahasiswa yang memiliki nilai tertinggi dari hasil perhitungan TOPSIS dan AHP yang di pilih.

\section{Daftar Pustaka}

[1] Marakas, George M. "Decision Support Systems in the 21st Century", 2nd Edition, Prentice Hall, 2003

[2] Saaty, Thomas L. The Fundamentals of Decision Making and Priority Theory with the Analytic Hierarchy Process Thomas L. Saaty Vol. VI of the AHP Series, , 478 pp., RWS Publ., 2000 (revised). ISBN 0-9620317-6-3.

[3] Sprague, Ralph, H \& Hugh, J. Watson, "Decision Support Systems", Prentice Hall, Inc., 1993.

[4] Turban, Efraim \& Aronson, Jay E., "Decision Support Systems and Intelligent Systems”, 8th edition, Prentice Hall, Upper Saddle River, NJ, 2007. 